\title{
IDEOLOGY AND SPIRITUALITY: \\ A CRITIQUE OF VILLA VICENCIO'S PROJECT OF RECONSTRUCTION
}

VS Vellem

Systematic Theology \& Theological Ethics

University of South Africa

\begin{abstract}
The relationship between ideology and spirituality does not only offer a critical view of the project of reconstruction from a Black Theological perspective, but it is also a significant question for the agenda of Black Theology of liberation in the $21^{\text {st }}$ century. This paper searches for the ideological assumptions that deeply underlie the proposal for reconstruction by reformulating it as a masqueraded proposal for a political theology. By further taking a critical view of the new order that instantiates the proposal for a reconstruction theology, caution in the journey between domination and hegemony resulting from a malignant convergence of public life by unredeemed spheres of politics and economics is made to underscore the dangers of convergence between ideology and spirituality.
\end{abstract}

Key Words: Ideology, Spirituality, Black Theology, Convergence, Public Life

\section{Introduction}

The demise of apartheid in South Africa coincided with epochal global events such as the fall of the Berlin Wall, perestroika, the rise of democracies, information revolution, and the unification of Germany all of which characterized what has generally been understood as globalization. Talk of the new world order became rife, and became an epoch that shaped public discourse as South Africa was ushered into a democracy. In the context of this new world order, Charles Villa-Vincecio (1992) proposed the motif of reconstruction as an alternative to liberation and ipso facto, Black Theology of liberation. It is in this era that Black Theology of liberation was subtly driven to the doldrums, regarded as moribund by some circles in our theological landscape in South Africa.

This paper argues that reconstruction does not alter the essence of Black Theology of liberation, but at least provides a mode, albeit ideological, of doing theology in the context of a legitimate power and state in South Africa. Put differently, the argument is that reconstruction cannot assume a pedestal of a governing symbol of liberation, especially Black Theology of liberation. At best, this argument for an alternative theological symbol after the demise of apartheid is ideological. To achieve our purpose, our argument will be premised on the assertion that reconstruction as proposed by Villa-Vicencio is inter alia, a particular kind of public theology. To assert that Black Theology of liberation, which has been discounted as moribund after the demise of apartheid, is not only a potential kind of 
public theology but, also, a public theology among others, unveils the ideological ramifications of the proposal for reconstruction. ${ }^{1}$

\section{A Brief Catalogue of Reconstruction as a Theological Paradigm}

Villa-Vicencio's project emerged within the climate of reconstruction and development in South Africa. The notion of reconstruction became rife in the transition period of South Africa. The African National Congress (ANC) had already begun to talk about the Reconstruction and Development Programme (RDP) later published as the ANC's election manifesto in a modified form in 1994. Alan Hirsch, commenting about the RDP document says that "the document was a blueprint for a productive social democratic haven," (2005:59). As we all know, this blue print of social democracy remains one of the central points of contestation in our land today.

As a theological paradigm, reconstruction began to gain momentum in the late 1980s and the beginning of the 1990s (Martey 2005:5). In 1987, at the Fifth General Assembly of the All Africa Conference of Churches, reconstruction was favourably proposed by Jesse Mugambi as a way forward for theology in Africa. The advocacy in favour of reconstruction mounted as it became clear that apartheid was coming to an end. Pityana (1995:229) also noted that African theologians were engaging with the concept of reconstruction. Farisani (2002) also makes this assertion. Jesse Mugambi was however, the first among African theologians to propose a departure from liberation to a reconstruction paradigm (Getui \& Obeng 2003: foreword; Martey 2005:5; Farisani 2002:63).

Central to the proposal to shift from liberation to reconstruction is the new world order, which demands reconstruction and renovation in the $21^{\text {st }}$ century. In the proposed shift, the post-exilic metaphor derived from Ezra-Nehemiah is mooted as an alternative to the Exodus metaphor usually linked to the liberation paradigm that is now viewed as inadequate to contend with the change that has taken place. In 2000 there was a theological conference held in Nairobi, Kenya. This theological conference brought together representatives from a variety of theological organizations in Africa. ${ }^{2}$ Note what Martey says:

At Mbagathi, the tension between liberation and reconstruction became obvious when the black theologians from South Africa including Takatso Mofokeng and Tinyiko Maluleke expressed dissatisfaction with Mugambi's attempt to downplay and underestimate the importance of liberation for Africa's social transformation and development. Reconstruction must begin with liberation as all Africans are not yet liberated (2005:6).

That 'reconstruction must begin with liberation' and that liberation cannot be downplayed is paradigmatic because comprehensive liberation is still to be attained by Africans. ${ }^{3}$ To

Cf. Vellem's paper “On Black South African Public Theology in a Global Era” to be published in Theologia Viatorum. See also Vellem's 2007:128-236 for a lengthier debate on reconstruction and Black theology of liberation.

2 These organizations were the Conference of African Theological Institutions (CATI); All Africa Conference of Churches (AACC); the Ecumenical Association of Third World Theologians (EATWOT); the Circle of Concerned African Women Theologians (THE CIRCLE); and the Organization of African Instituted Churches (OAIC).

3 This point is important to reckon as an analysis of various strands in Black Theology of liberation has been made. A good example we can offer is Ntintili's (1996) article which examines the notions of liberation in Black theology. Certainly in the history of this intellectual tradition, the debates such as the one on the differences between African Theology and Black Theology of liberation, the Race and Materialist approaches are well-documented and signify that there have been many strands and multiple views about the methodological approaches of this school. All this ultimately points to is the comprehensive nature in which the notion of 
maintain that liberation should be a starting point of reconstruction is substantively different from arguing for the shift from liberation to reconstruction.

In essence, the statement that reconstruction must begin with liberation implies that reconstruction is not a quid pro quo for liberation rather liberation is a sine qua non of reconstruction. Liberation is the comprehensive framework within which reconstruction and development can find their place. The Mbagathi text above is lock, stock and barrel an indication of the ideological implications fraught with the proposal for reconstruction.

Martey (2002:7) further points to another Conference that was held in South Africa that was slightly different in tone. It was this conference on Theological Education and Ecumenical Formation in 2002 that saw liberation and reconstruction as complementary paradigms "for Africa's liberative reconstruction and sustainable development." In the end, there were two conferences that engaged the metaphor of reconstruction. The inadequate attention to the comprehensive nature of liberation by the proposers of reconstruction was perhaps the most outstanding feature of the Mbagathi Conefrence. The South African one sought to attain a reciprocal relationship between reconstruction and liberation. Liberation though seemed to have been placed as a governing symbol for reconstruction and sustainable development. Let us now examine Charles Villa-Vicencio's views on reconstruction (1992).

\section{Villa-Vicencio's Tenets of Reconstruction Theology}

In his major work on the proposal for reconstruction as a new theological metaphor, VillaVicencio clearly states his intention to propose an 'unambiguously interdisciplinary' methodological approach to his project of reconstruction and theology.

The context that informs this project is the perestroika (reconstruction by Gorbachev), associated with the shift of events on the globe marked inter alia by the fall of the Berlin Wall. This shift also marked the dawn of democracy in South Africa. Some called this the new world order. ${ }^{4}$

The new world order connotes the disintegration of the Union of Soviet States of Russia (USSR), the demise of apartheid, the reunification of Germany, moves to create a unitary Europe, the emergence of democracies in Third World countries and globalization. According to Villa-Vicencio reconstruction is a response to the challenge of the church whose theological task is to restore justice and to affirm human dignity, ensuring that in the process of reconstruction nations are able to turn away from greed, domination and exploitation to communal sharing and personal fulfillment (1992:2). Reconstruction is a process that entails a metanoia (transformation) of social ills in order to usher in communal sharing and personal efficacy.

With the political void having lapsed since the un-banning of political organizations in South Africa, the need to move from saying 'No' to saying 'Yes' has arisen. As VillaVicencio points out, the type of theology of reconstruction demanded by this challenge to move from saying 'No' to saying 'Yes' is in every sense a post-exilic theology. Recon-

liberation unfolded which cannot be downplayed, or overlooked if a serious engagement with this intellectual tradition is to be attained.

4 I am aware of the fact that the notion "new world order" has attained some new meaning since the era of George W Bush. Bush sees the new world order through the spectacles of what he calls "the axis of evil" referring to such countries as Iraq, Palestine, Afghanistan etc, the politics of which he intends to put in order. I am also aware of the fact that $9 / 11$ has also brought into the global order new dimensions that were not there in the late 1980s at the fall of the Berlin Wall and the dawn of democracy in South Africa. 
struction addresses a situation within which political exiles are quite literally returning home, having left the country in steady streams since the banning of the African National Congress and the Pan African Congress in 1960. Reconstruction involves the task of breaking down prejudices of race, class and sexism, and the difficult task of creating an allinclusive society built on the very values denied the majority of the people under apartheid. As this challenge is met, Villa-Vicencio maintains, it could mean the birth of a different kind of liberatory theology (1992:7-8).

To restate, reconstruction theology is a post-exilic theology. Villa-Vicencio argues that there are resources in the Biblical literature of the post-exilic times that give credence to the appropriation of the post-exilic metaphor as a prophetic theology of reconstruction. The main interlocutors of the reconstruction are 'political exiles' who have steadily streamed into the country since the banning of the liberation movements. Reconstruction is therefore, a call for a metanoia from social prejudices and a creation of a new society built on the values of the masses of South Africa.

This kind of theology however, Villa-Vicencio argues, should be radically interdisciplinary and emerge at the interface between theology and law, economics, political sciences and related disciplines. Further to the attributes given above, reconstruction theology will involve the theological wisdom passed on for ages in public life ${ }^{5}$ because the church cannot abandon its responsibility to participate in public life.

In his reference to Tillich and Barth, Villa-Vicencio (1992:22-5) demonstrates the immense difficulties that go along with any legitimating theology in times of reconstruction. The dilemma as to whether the issue of contributing to good governance is something that the church ought to relinquish and leave to the politicians is an old question about the church-state relations. According to him, reconstruction theology has a role to deal with the vestigial realities of apartheid. In doing so, reconstruction theology will employ the utopian visions created by prophets, preachers and poets. These visions, however, will need to be translated into social practice and operative laws. Villa-Vicencio contends that often social practices and operative laws fall short of the vision of the life-giving power of theology which must be embedded in the realities of everyday life. What this means is that reconstruction theology should function as an inspiration for social vision and renewal even if the translation of that vision falls short of the vision itself.

The ethic of reconstruction is one of 'middle axioms,' meaning the provisional values and structures, which begin the process of renewal within the limitations and context of one generation. Middle axioms, Villa-Vicencio (1992:9) argues, are ethical principles 'not binding for all time' but, 'begin' the process of social renewal. In other words, middle axioms are evolving principles in the process of social reconstruction "seeking to define the next logical step society needs to take at a given time" (1992:280). Villa-Vicencio implies that middle axioms should be perceived as 'anchors and compasses' of a utopia of reconstruction. These are ethical principles that state what the gospel demands are at a given time and space. Villa-Vicencio employs the notion of the middle axioms as a contextual device to locate reconstruction theology within theory and practice. Following on Pityana (1995), reconstruction implies that there is a structure onto which a new one should be built. It might be safe for us to perceive these middle axioms as structures of principle on which the utopia of reconstruction must be anchored. The notion of 'middle axioms' is about the application of ethical principles in a given time and space as the church is required to

That designation is specifically mine as it is not used by Villa-Vicencio himself. The main thought here is that theology must be involved in public life. 
"support certain specific political and economic proposals and not support others" (1992:283).

In the chapter on 'Theology and Nation-building,' Villa-Vicencio provides a framework of entry into public life which he defines as 'religionless' (1992:28). By this he means that the language of religion should be altered in such a way that it makes sense even to those whose assumptions and beliefs are not informed by religion. Clearly the rationale for an 'unambiguously interdisciplinary' approach is behind the assertion. For example, he looks at the political task of the Church and posits:

Christians in places where transition and renewal are happening need not, and probably should not, follow the theological models of the First World any more than they need to follow their political, economic and social inventions. The existence of African, black and other contextual theologies in South Africa, together with Third World and liberation theologies elsewhere suggests that the break with classical theology has already taken place. In struggling to discover what it means to be theo-politically responsible in a time of political transition, Christians in these situations would, however, do well to learn from the insights and mistakes of others who have grappled with similar programmes of theological and political reconstructions in earlier times (1992:37-38).

The ominous task of creating a language and structure of a theo-political responsibility in new situations is central to our discussion in this paper. Let us recapitulate. First, reconstruction theology is a process that entails a transformation of society from social ills of racial and gender prejudice coupled with economic degradation. Second, the key metaphor of the theology of reconstruction is the post-exilic corpus of Ezra-Nehemiah. There is an inherent prophetic dimension to the metaphor as well. Third and related to the point above, reconstruction theology is a form of 'religionless' theological participation in public life and policy formulation. To achieve this objective of participation in public life, a strategy of an 'unambiguously interdisciplinary' theological enterprise expressing its faith ideals and vision in a religionless manner must be adopted. Fourth, its ethical character is expressed through the notion of 'middle axioms' i.e. contextual devices applicable in a given time; hence its praxiological orientation is informed by the notion of transitional ethical principles. Last, it is ideologically a theology of the perestroika, a step by step theological engagement in renewal, economic transformation and nation-building purported to be more than the ideals of revolution. All these point to the contours of a theo-political language and structure in a new situation as perceived by Villa Vicencio. Let us however try to establish what he says about liberation itself before we critically engage the theo-political language and structure of reconstruction theology.

\section{Reconstruction and Liberation by Villa-Vicencio}

In Villa-Vicencio's endeavour, clearly a quest for a new kind of liberating theology $(1992: 13)$ is pursued. Because reconstruction theology is a new kind of liberation theology, Villa-Vicencio recognizes the concern around theology as a potentially dangerous device in the arena of power which results in hesitation by some theologians to move beyond what they regard as legitimate forms of liberation theology in spite of the need to engage constructively in nation building. As a new liberation theology, the hermeneutical relationship between past and present finds its dynamic liberating exercise in the notion of the postexilic church with some form of a hermeneutic of suspicion, because not all within the exilic and post exilic periods is readily usable and appropriate for liberation. 
Villa-Vicencio further maintains that the response of liberation theology to a church on the side of the oppressive regimes is hope and promise. The challenge now is to translate that hope and promise into concrete theological programmes of home-coming and nationbuilding. In doing so, the church in developing reconstruction theology will learn from other places. As a liberation theology, reconstruction stands for radical transformation (1992:39). Revolutionary fervour was 'inserted' into the mainstream theology by the paradigm of liberation and by implication the same revolutionary fervour will not be lost if reconstruction becomes a theology of liberation. Because liberation theology has not produced the strategies of reconstruction, a new metaphor of reconstruction must be explored in order to shift the paradigm from 'No' to 'Yes.' In an article which suggests a move beyond liberation theology for an apparent new theology for South Africa, Villa-Vicencio himself says (1993:24):

Liberation theology in South Africa has been essentially a theology of saying 'No'. It required us to say a simple and firm 'No' to apartheid, racism, sexism, exploitation and all phoney (sic) forms of reform. We did not have to be very thoughtful or intelligent to get this right. A little guts was all that was required of most of us - although some, of course, paid dearly for daring to say 'No'.

The first assertion is that the essence of liberation theology is to say 'No'. The second is that liberation theology was neither thoughtful nor intelligent a theology. Last, it was a theology of the guts. It might be better to hear how other voices have responded to VillaVicencio's call for reconstruction before I respond.

First I concur with Farisani that Villa-Vicencio does not give a detailed analysis of liberation theology (2002:64). Farisani also sees a strong praxis oriented proposal which emerges from the context of the struggle in the proposal for reconstruction (2002:68). Yes, indeed it is interdisciplinary and does not re-invent the wheel, but seeks to unleash the dangerous power of liberation in human rights; interfaith dialogue; cultural empowerment and economic justice in an open-ended manner. Maluleke (1994a; 1994b) is among those who have sharply criticized the project of reconstruction on the basis that it takes very little account of the ground covered by the heritage of liberation theologies in South Africa. Reconstruction needs to begin with liberation. On the other hand, Pityana (1995) argues that Villa-Vicencio's project is not hostile to the liberation project as it is couched within the genre of liberation theology. Pityana's point is that something new has happened, a new situation has arisen.

According to him, dialogue with the Enlightenment paradigm is important. Furthermore in questioning Villa-Vicencio's commitment to liberation, his past contribution to the tradition of liberation must be taken into account.

Farisani's criticism comes from another angle. While acknowledging that Villa-Vicencio is not a biblical scholar and commends him for his cautious appropriation of the postexilic metaphor of Ezra-Nehemiah, it is the question of the ideology between the am haaretz (the people of the land) and the exiles which he finds to be inadequately addressed by Villa-Vicencio and Mugambi (Farisani 2002:86; 2003:30). He says:

My main critique is that Villa-Vicencio's use of Ezra-Nehemiah does not examine critically the ideology behind the conflict between the returned exiles and the am haaretz. A careful reading of the text of Ezra-Nehemiah demonstrates that there is a contestation between at least two groups, namely the returned exiles and the am haaretz. It follows therefore that if Ezra-Nehemiah is to be used in the theology of reconstruction, it should not be read as representing the voice of only one group i.e. that of the returned exiles (2002:30). 
It is safe to conclude that Farisani argues that a complete break from liberation is not possible. He suggests that an 'oscillation' between liberation and reconstruction is the way forward. Surely this oscillation should take into account the ideological constraints between reconstruction and liberation. Farisani, with whom I agree, refuses to jettison the liberation paradigm and argues for sensitivity to ideology. The fact that Villa-Vicencio does not give a detailed analysis of liberation theology to support his call should be seen in this light, an ideological omission of liberation theology's potential to offer a responsible theo-political language and structure after apartheid. Maluleke however, struggles to locate this endeavour within the genre of liberation theology, because Villa-Vicencio appears to minimize the value of liberation and inculturation (1997:23). While I warm up to these views, I suggest that we need to reformulate our question in a different way in order to dissect this problem further.

\section{A Reformulation of Reconstruction as Public Theology}

My analysis of the reconstruction project will be anchored on the assumption made with regard to the topography of Black Theology of liberation and other liberation theologies. It has been common to view Black Theology of liberation as not 'clinical' or 'pure' theology and public theology. This kind of an assumption is a 'taken-for-granted-substratum' that runs undisclosed in his proposal. So it is not only the call to move to a post-exilic paradigm which is essentially problematic for me, but the treatment of the essence of liberation or Black Theology of liberation which he implicitly disparages as thoughtless, unintelligent, but only a theology of the guts.

The problem of ambivalence in this proposal for reconstruction is captured well by the different critiques we have thus far highlighted due to the ambiguous nature in which continuity and discontinuity with liberation is actually handled. Mark this ambivalence: "Villa-Vicencio's project proposes a departure from liberation to reconstruction even though this reconstruction will still remain liberatory." ${ }^{\circ 6}$ There are essential tenets in Black Theology of liberation which cannot be simply discarded if one wishes to be within that paradigm. The preferential option for the poor or a black non-person is confused with new interlocutors in this proposal and thus creates an unsavory ambivalence between his proposal and the liberation paradigm. Interlocution w seems to be utterly confused in the project of reconstruction. This ambivalence makes it difficult to understand what the departure from liberation is or what Villa-Vicencio means by reconstruction as an alternative to liberation while he still clings to liberation.

Apart from this ambivalence, to reformulate reconstruction as a public theology, I take my cue also from concepts such as 'religionless,' 'participation' and perestroika. Perestroika calls upon the church to make sense of its theological values beyond its membership and engage in a secular debate in a language understandable to a broad constituency of people (Villa-Vicencio 1992:4). Our key to demystifying the project of reconstruction is found in what Villa-Vicencio says:

In this particular study, an attempt is made to make sense, in terms of this tradition, of the history of the struggle for socio-economic, political and cultural liberation and national reconstruction within the South African context identifying the implications of this for a political theology of more universal kind (1992:24)

6 The word, liberatory, is used by Villa-Vicencio himself. 
Let me clarify that the tradition referred to is the Judeo-Christian one, rendered marvelously by Villa-Vicencio to signify the human quest for wholeness in all situations and dimensions of life. Reconstruction is therefore an attempt to appropriate the struggle for liberation within the South African context by identifying the implications of such a struggle for a more 'universal kind of political theology.' This is where the problem lies for me.

First, it is the debate between public theology and liberation theology that has been omitted. Let us remember that public theology developed from political theology and the dialogue between political theology and Black Theology is a well documented fact (Cf. Maimela 1991). Koopman (2003:3) says:

This concept [public theology] was used for the first time by the North American theologian Martin Marty in an article that analyzed the thought of Reinhold Niebuhr, entitled 'Reinhold Niebuhr: Public Theology and the American Experience.'

There has been a pervasive understanding that public theology had a distinct topography and in the case of our context, the implication has been that Black Theology is not public theology. We discern this in Villa-Vicencio's assertion that liberation needs to be abandoned as there are 'experiences elsewhere' that must inform us in the construction of a new language of doing theology in this new situation. The proposal to move from liberation to reconstruction avoids the debate between political theology and Black Theology of liberation in South Africa in favour of 'political theology of a universal kind.' But there is no one form of public theology (Koopman 2003; Storrar \& Morton 2004). Black Theology of liberation and liberation theologies are public theologies in their own right.

Kee (1986:46) affirms that Deotis Roberts wrote A Black Political Theology which made him stand within the tradition of public theology. On our shores, Maimela (1991) addresses the question of political theology and how it differs from Black Theology of liberation. To the extent that Black theology has reflected on the question of black power, it is public because publicity is about power. Publicity is in some sense about the division of power. The quest for a universal political theology by Villa-Vicencio falls short at this point. From this the assertion made by Villa-Vicencio that the divide between First and Third World theologies needs to be challenged and overcome is at best ideological (1992:15). There is no divide but, essentially, a break with classical theology. There is an ideological break.

I affirm the ideological uneasiness expressed by Farisani. Maluleke's charge that the ground covered needs to inform new innovations holds water too (1997:23). Covering this ground is one matter. Occlusion of this ground is yet another. About reconstruction itself Pityana says:

Its methodology of interfacing with economics, human rights law and political science is conducted in an uncritical manner without regard to the fact that these very systems from which theological discourse was to draw were themselves flawed. In other words little attention was paid to the critical approaches to historiography and jurisprudence. Such an interdisciplinary effort lands on the laps of tight and unredeemed academic discourses which themselves need to be interrogated and deconstructed (1995:38).

Let us conclude this section by stating in a concise manner the principles that we have used. The fulcrum of my critique, in addition to what others have said is that reconstruction disguises a proposal for a public theology of some universal kind. This is very important in our context in the light of the 'currency' of public theology after the demise of apartheid. My contention is that the kind of public theology proposed by Villa-Vicencio is methodologically and ideologically, not within the framework of liberation or at least Black 
Theology. It is fascinating to observe how Boesak (1976:57) used the interfusion of 'Yes' and 'No' for Black Theology of liberation some years ago:

Black Power's concern is the essential humanity of black people. Its concern is selfaffirmation, self-respect, pride, participation in and control of black's own human destiny. It says 'Yes' and 'No.' Indeed but 'Yes' and 'No' to what? It is in this choice that the fulfillment of black authenticity lies.

The significance of this quotation lies in the fact that the interfusion of 'Yes' and 'No' is a power matter for the essential humanity of black people. Most importantly, the whole constellation of liberation is not based on 'No' but 'Yes' and 'No.' The essential 'No' of Black Theology of liberation cannot be equated only to the fall of apartheid. The essential 'Yes' of Black Theology of liberation too cannot be occluded from the affirmations we need in public life today. There will be no public theology in South Africa without Black Theology of liberation. Black Theology of liberation is an intellectual tradition, thoughtful and intelligent in essence.

\section{The Significance of Ideology and Spirituality in Black Theological Discourse}

In the twenty first century requires us to depart from binary views of the world. Ideology and spirituality need dire attention therefore in the discourse of Black Theology of liberation. The discussion we have had thus far points to the unavoidability of ideology in doing theology even in situations of change. The primary challenge of unipolarity in this century should alert us to the imminent danger of convergence in public life. I make three related points to debunk the hegemonic challenges in this century.

First, we need to remember that the treatment of issues such as 'universality' and 'particularity' by scholars such as Mosala (1989:21-26; 73) demonstrate the role that ideology plays in theology. It should remind us of the ideological rupture of the liberation paradigm from traditional forms of doing theology. Theology is particular. It is in its particularity that its universal dimension should be sought. To the extent that ideology is one inevitable component of analysis in Black Theology, Takatso Mofokeng (1983) goes even further to suggest that in the intricate relationship between Black Consciousness and Black Theology, it may not even be impossible to argue that Black Consciousness is a product of Black Theology of liberation. This link between Black Theology of liberation and Black Consciousness can only be overlooked for ideological reasons. Critical questions about the 'newness' of the new world order (Maluleke) surely help us interrogate the ideological choice of a new interlocutor in the proposal for any new theology in South Africa. Black Theology of liberation was not meant to be integrated into another value system of theology as the proposal for reconstruction seems to suggest.

Second, and quite briefly so, the hegemony of one ideological view in the new world order, apparently converging all spheres of life into a global monologue exemplified by the alleged 'victory' of capitalism over socialism and the assertion that history has come to an end (Fukuyama), should tell us that the Berlin Wall and the apartheid walls are simply invisible but prevalent among us. The apparent absence of 'walls' points to deeply entrenched ideological performances in public life because:

An ideology is a shy creature: it does not want to be seen, to be identified, to be named. It would rather that its view of reality were simply taken for granted, without further thought. It rests content if its values and prejudices are simply assumed as too obvious to be contested...Ideology chuckles behind its hand. No evaluation is required of mainline society. Its essential health and virtue are simply assumed. Its part in exclusion is never 
examined. The possible and potential role of the excluded in the regeneration of society is not even envisaged. The fact of their exclusion is not seen as a symptom of disorder, neither as a witness to corruption (Kee 2004:352).

Many of the assumptions behind the proposal for reconstruction are simply assumed. But this is how the current world order simply functions today where a shift from domination to hegemony simply makes ideology to 'chuckle behind its hand.' That there was no evaluation of the newness of the situation in South Africa and mainline society is simply assumed with its essential health and virtues can only be understood as a deep challenge recalling what Pityana calls 'unredeemed' and 'tight' academic fields including politics and economics that cannot be uncritically accepted. Contesting for a space in public life is ideological and Black Theology of liberation has to deal with hegemonies that perpetuate the impoverishment of the poor and the degradation of all creation today. The analysis of the current world order shows ${ }^{7}$ that there is a contraction of the space of normative values in public life. The convergence of power and money commodifies the whole of life hence the affirmation of life from the tradition of Black Theology of liberation remain indispensable in public life today.

Last, the relationship between ideology and spirituality is thus an important question for Black Theology of liberation in its dialogue with the current world order. The link between Black Consciousness and Black Theology suggest a profound link we need to make between spirituality and consciousness. That there is a rise of spiritual yearning and hunger in our world today could be a sign of a malicious convergence between ideology and spirituality. The tension between ideology and spirituality is a vital space for Black Theology to unveil the space between domination and hegemony.

\section{Conclusion}

This paper is not conclusive but tentative. It has attempted to critically view the proposal for reconstruction from a Black Theological perspective to demonstrate how deeply ideological some of the innovations can be. While having shown how other scholars critiqued the proposal for reconstruction by Villa-Vicencio, by reformulating the question of reconstruction as a proposal for a particular kind of political theology, an attempt to unveil the underlying ideological ramifications of the project has been made.

Indeed if ideology and spirituality are so related, given the shift from a binary world, Black Theology of liberation has a lot to offer in this century by affirming life. The religion of a 'white man' even after the demise of apartheid needs a clear 'No'. While ideology and spirituality are mystic and difficult concepts to grapple with, the rise of religion in this century should alert the exponents of Black Theology of liberation to the danger of unipolairty which converges ideology and spirituality to the destruction of the conviviality of life. 


\section{BIBLIOGRAPHY}

Boesak, A 1976. Farewell to Innocence. A Social-Ethical Study of Black Theology and Black Power. Johannesburg: Raven.

Boesak, A 1977. Farewell to Innocence: A Socio-ethical study of Black Theology and Power. Maryknoll, New York: Orbis.

Getui, MN, \& Obeng, EA (eds.) 2003. Theology of Reconstruction: Exploratory Essays. Nairobi: Acton Publishers.

Farisani, E 2003. 'The Use of Ezra-Nehemiah in a Quest for an African Theology of Reconstruction', Journal of Theology for Southern Africa, 116, 27-50.

Farisani, E. 2002. 'The Use of Ezra-Nehemiah in a Quest for an African Theology of Reconstruction', $\mathrm{PhD}$ thesis, School of Religion and Theology, University of Kwa Zulu-Natal.

Fukuyama, F 1992. The End of History and the Last Man. New York: Avon.

Habermas, J 1981. The Theory of Commincative Action. Vol. 1, Reason and the Rationalization of Society, transl. T McCarthy. Boston: Beacon.

Habermas, J 1987. The Theory of Communicative Action: Lifeworld and System: A Critique of Functionalist Reason, Vol. 2. Boston: Beacon.

Hirsch, A 2005. Season of Hope: Economic Reform under Mandela and Mbeki. Scottsville: University of KwaZulu Natal Press.

Kee, A 2004. 'Blessed are the Excluded' in WF Storrar and Morton, AR (eds.), Public Theology for the $21^{\text {st }}$ Century, pp.351-364. London: T\&T Clark.

Kee, A 1986. Domination or Liberation. The Place of Religion in Social Conflict. London: SCM.

Koopman, N 2003. 'Some Comments on Public Theology Today', Journal for Southern Africa 117, 3-19.

Maimela. S 1991. Modern Trends in Theology. Johannesburg: Skotaville.

Maluleke, TS 1994a. 'Review', Villa Vicencio, C, 1992, A Theology of Reconstruction. Nation and Building and Human Rights. David Philip, Cape Town, Missionalia 22(2), 186-188.

Maluleke, TS 1994b. 'The Proposal for a Theology of Reconstruction: A Critical Appraisal', Missionalia, 22(2), 254-258.

Maluleke, TS 1996a. 'Black and African Theologies: A Time to Drink from our Own Wells', Journal of Theology for Southern Africa 96, 3-19.

Maluleke, TS 1996c. 'African Culture, African Intellectuals and the White Academy in South Africa,' Religion and Theology3 (1), 19-42.

Maluleke, TS 1997. 'Half a Century of African Theologies', Journal of Theology for Southern Africa 99, 4-23.

Martey, E 2004. 'Theology and Liberation: The African Agenda', presented at the World Forum on Theology and Liberation, Porto Alegre, January.

Mofokeng, T 1993. 'The Crucified and Permanent Cross-bearing', Journal of Black Theology 1, 20-30.

Mofokeng, T 1983. The Crucified among the Crossbearers: Towards a Black Christology. Kampen: JH Kok. 
Mosala, I 1989. Biblical Hemerneutics and Black Theology in South Africa, Wm B Eerdmans, Grand Rapids, Michigan.

Mugambi, JNK 2003. Christian Theology and Social Reconstruction, Acton Publishers, Nairobi.

Mugambi, JNK 1995. From Liberation to Reconstruction: African Christian Theology after the Cold War. Nairobi: East African Educational Publishers.

Ntintili, V 1996. 'Notions of Liberation in Black Theology: Which is more liberative?' Journal of Black Theology 10(1), 1-17.

Villa-Vicencio, C 1992. A Theology of Reconstruction, Cambridge, Cambridge.

Villa-Vicencio, C 1993. 'Beyond Liberation Theology: A New Theology for South Africa', Challenge Magazine, 24-25.

Villa-Vicencio, C 1991. 'The Kingdom of God and People's Democracy: Towards a Nation-Building Theology for Africa', Journal of Theology for Southern Africa, March, 3-13.

Pityana, B 1995. 'Beyond Transition: The Evolution of Theological Method in South Africa. A Cultural Approach', PhD thesis, Dept. of Religious Studies, University of Cape Town.

Vellem, VS 2007. 'The Symbol of Liberation in Public Life: A Black Theological Perspective', PhD thesis, Faculty of Theology, University of Pretoria. 